\title{
Debulking keloid pada telinga kiri
}

\author{
Ennesta Asri ${ }^{1}$, Sri Lestari ${ }^{1}$, Nadya Hasriningrum², Meligasari L. Gaya ${ }^{2}$
}

\begin{abstract}
Abstrak
Pendahuluan: Keloid adalah lesi proliferatif jinak dari jaringan konektif dermis yang biasanya dihasilkan dari respon jaringan terhadap trauma kulit pada orang-orang dengan predisposisi, dimana tidak sembuh secara spontan. Terapi keloid dipilih bergantung pada ukuran lesi, lokasi, kedalaman lesi, usia pasien dan respon terhadap pengobatan terakhir. Terapi pembedahan pada keloid yang besar dan tidak bertangkai seperti keloid pada daun telinga merupakan pilihan. Kasus: Dilaporkan satu kasus debulking keloid di daun telinga kiri pada laki-laki 19 tahun. Pasien mengeluhkan timbul benjolan sewarna kulit yang terasa sedikit gatal di daun telinga kiri sejak 1 tahun yang lalu akibat luka robek kecelakaan lalu lintas 2 tahun yang lalu. Tidak ada riwayat pengobatan sebelumnya pada benjolan tersebut. Pada pemeriksaan fisik keadaan umum baik, tanda vital dalam batas normal. Status dermatologikus pada helix aurikula sinistra didapatkan adanya skar hipertrofik dengan ukuran $2 \mathrm{~cm} \times 1 \mathrm{~cm} \times 0,5 \mathrm{~cm}$, permukaan licin, keras, mengkilat, imobile, dan telangiektasis. Pasien dilakukan debulking keloid menggunakan anestesi lokal dengan lidocaine $2 \%+$ pehacaine 1:80.000. Setelah 3 minggu paska operasi, luka baik dengan ukuran keloid mengecil. Pasien direncanakan injeksi triamsinolon acetonide $40 \mathrm{mg} 1 \mathrm{minggu}$ lagi. Diskusi: Lini pertama terapi keloid adalah injeksi kortikosteroid intralesi. Kombinasi bedah dan triamsinolon asetonid intralesi dapat mencegah kekambuhan keloid.
\end{abstract}

Kata kunci: Debulking keloid, tehnik, tatalaksana

\begin{abstract}
Introduction: Keloid is a benign proliferative lesion of the connective tissue on dermis resulting from tissue response to skin trauma in predisposing people, which not recover spontaneously. Keloid therapy is selected depending on size, location, and depth of the lesion, patient age and response to recent treatment. Surgical treatment of large and non-shaft keloid like keloids in the earlobes is an option. Case report: Reported a case of debulking keloid in the left earlobe in 19-year-old male. Patient complained of skin-colored lumps that felt little itchy in the left ear leaf since 1 year ago because traffic accident injury 2 years ago. No previous medical history on the lump. Physical and vital sign examinations were within normal limits. Dermatological state in the helix aurikula sinistra found hypertrophic scars, size $2 \mathrm{~cm} \times 1 \mathrm{~cm} \times 0.5 \mathrm{~cm}$, slippery surface, hard, shiny, imobile, and telangiectasis. Patient performed a debulking keloid using local anesthesia 2\% lidocaine + pehacaine 1: 80.000. After 3 weeks postoperatively, the wound was good and size of keloid smaller. Patient planned triamcinolone acetonide injection $40 \mathrm{mg} 1$ week later. Discussion: The first line of keloid therapy is intralesional corticosteroid injection. The combination of surgical and intralesional triamcinolone acetonide may prevent keloid recurrence.
\end{abstract}

Keywords: Debulking keloid, technique, treatment

Affiliasi penulis : 1. Bagian IImu Kesehatan Kulit dan Kelamin RSUP dr. M. Djamil Padang/Fakultas Kedokteran Universitas Andalas, Padang, 2. PPDS Dermatologi dan Venereologi Fakultas Kedokteran Universitas Andalas, Padang.

Korespondensi : Ennesta asri [ennestaasri@gmail.com] Telp: 0751-810256

\section{PENDAHULUAN}

Keloid merupakan pertumbuhan hiperproliferatif kolagen dermis yang bersifat jinak pada lokasi luka dan penyembuhan luka. Keloid kadang terasa gatal, sedikit nyeri, dapat menyebabkan gangguan secara kosmetik dan kontraktur kulit. ${ }^{1,2}$

Keloid adalah masalah yang sering dihadapi oleh dokter spesialis kulit. Kebanyakan mengenai usia 10-30 tahun. Kejadian keloid dilaporkan antara 4,5\%$16 \%$ dan kebanyakan didapatkan pada orang-orang kulit hitam, Asia dan Hispanik..$^{3,4}$

Patologi skar atau keloid masih belum dimengerti sepenuhnya. Dalam penelitian in vitro menunjukkan bahwa skar dianggap sebagai akibat dari penyembuhan luka yang abnormal, karena proliferasi fibroblast berlebihan diikuti oleh aktivasi kolagenase yang rendah. ${ }^{4,5}$

Manifestasi klinis keloid sangat bervariasi dan menggambarkan bentuk trauma. Lesi keloid biasanya muncul sporadis di daerah yang terkena trauma. Kadang-kadang ditemukan keloid yang luas. Deltoid, sternum, daerah punggung atas dan telinga merupakan area paling sering dikenai. Keloid dapat muncul dengan berbagai ukuran dari beberapa milimeter sampai diameter sebesar sepak bola atau lebih besar. Keloid pada telinga, leher, lengan dan perut cenderung bertangkai, sedangkan keloid sternum, punggung atas, dan ekstremitas biasanya besar, permukaan datar, dengan dasar lebih lebar dari atas. ${ }^{1,2}$

Terapi keloid dipilih berdasarkan beberapa faktor, diantaranya: ukuran lesi, lokasi, kedalaman lesi, usia pasien, dan respon pengobatan sebelumnya. Eksisi 
bedah, radiasi, terapi tekanan, krioterapi, injeksi kortikosteroid intralesi, interferon dan fluorourasil, silikon topikal dan dressing lainnya, serta pulse-dye laser. Modalitas ini dilaporkan dengan berbagai tingkat keberhasilan dan pembedahan sering menyebabkan kekambuhan. Kombinasi terapi bedah dengan terapi farmakologis seperti intralesi triamsinolon asetonid paska injeksi akan mencegah kekambuhan dari keloid. $1,2,6,7$

\section{LAPORAN KASUS}

Seorang pasien laki-laki umur 19 tahun datang ke Poliklinik Kulit dan Kelamin RS. dr. M. Djamil Padang dengan keluhan timbul benjolan sewarna kulit yang terasa sedikit gatal pada daun telinga kiri sejak 1 tahun yang lalu. Dua tahun yang lalu pasien mengalami kecelakaan sepeda motor menyebabkan luka robek pada daun telinga kiri. Tidak ada riwayat pengobatan sebelumnya pada benjolan tersebut. Tidak ada riwayat muncul bekas luka yang melebar dari batas luka dengan permukaan licin sebelumnya. Tidak ada riwayat anggota keluarga yang memiliki bekas luka yang melebar dari batas luka dengan permukaan licin. Pada pemeriksaan fisik keadaan umum baik, tanda-tanda vital dalam batas normal. Status dermatologikus pada helix aurikula sinistra didapatkan adanya skar hipertrofik dengan ukuran $2 \mathrm{~cm} \times 1 \mathrm{~cm} \times 0,5 \mathrm{~cm}$, permukaan licin, keras, mengkilat, imobile, dan telangiektasis (gambar 1 dan 2).

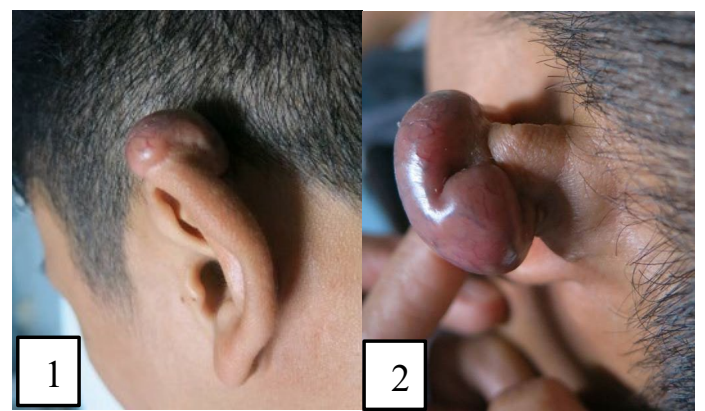

Gambar 1 dan 2. Skar hipertrofik pada helix aurikula sinistra

Pasien diterapi dengan debulking keloid setelah pemeriksaan faktor pembekuan darah normal, dengan prosedur tindakan sebagai berikut: pertama, dilakukan tindakan aseptik dan antiseptik dengan Betadine $\AA$ dan alkohol $70 \%$. Selanjutnya, dilakukan anestesi lokal menggunakan lidokain $2 \%$ + pehakain 1:80.000 dengan total $2 \mathrm{cc}$, disuntikkan ke bawah keloid (gambar 3). Eksisi jaringan keloid (gambar 4), lalu sisa jaringan keloid dibersihkan dari daerah sekitarnya (gambar 5). Lakukan revisi intra keloidal debulking dengan cara "trap-door"(gambar 6). Kemudian sisa jaringan keloid secara hati-hati menutupi badan keloid, dijahit menggunakan Silk 4.0 (gambar 7). Terakhir, oleskan salep antibiotik, dan tutup luka dengan verban.

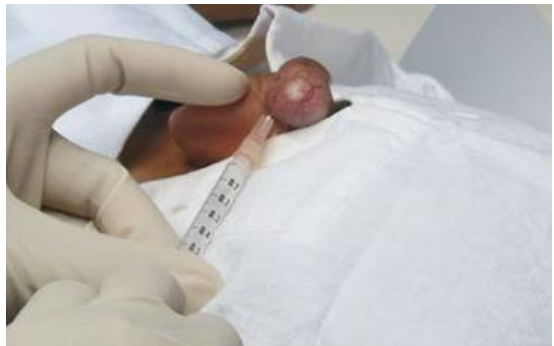

Gambar 3. Tindakan anestesi

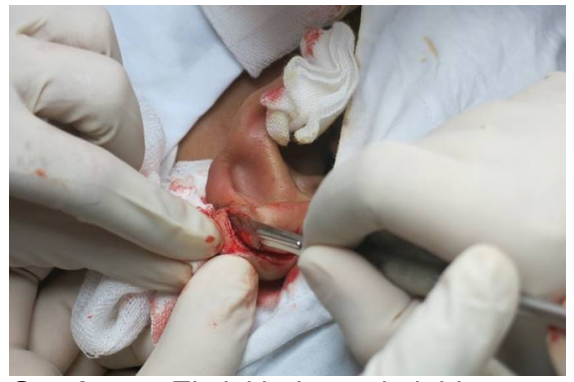

Gambar 4. Eksisi jaringan keloid

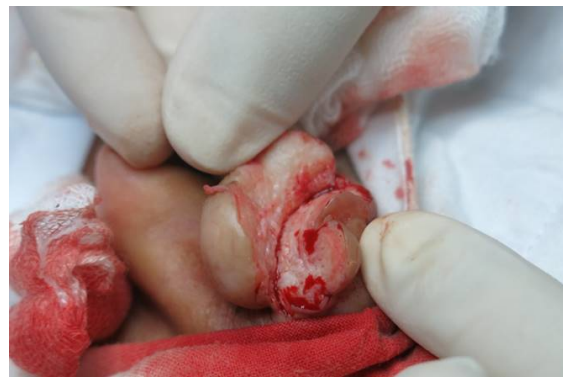

Gambar 5. Bersihkan sisa jaringan keloid dari daerah sekitarnya

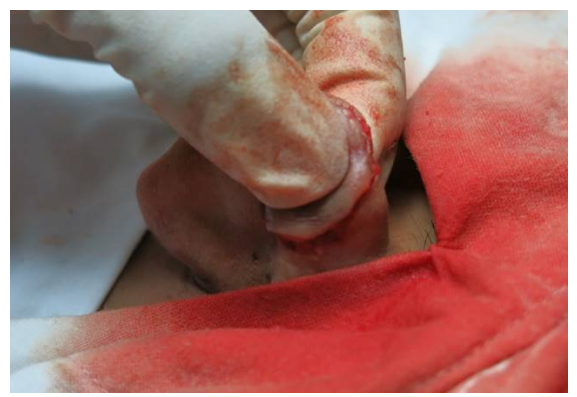

Gambar 6. Revisi intra keloidal debulking dengan "trap-door"

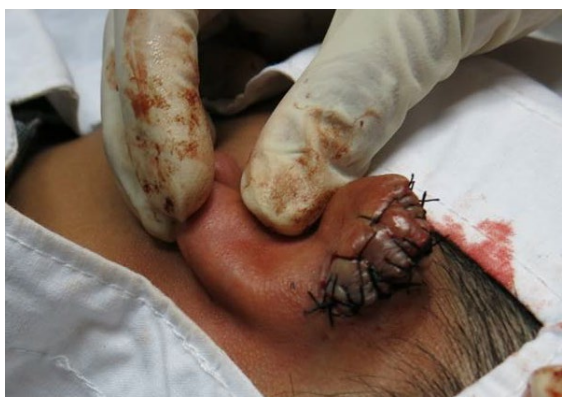

Gambar 7. Penjahitan sisa jaringan keloid

Pasien diberi obat ciprofloxacin tablet $2 \times 500$ $\mathrm{mg}$, asam mefenamat tablet $3 \times 500 \mathrm{mg}$, dan dianjurkan kontrol 1 minggu kemudian. Setelah 1 minggu jahitan 
dibuka selang-seling karena jahitan belum menyatu seluruhnya. Luka jahitan menyatu seluruhnya setelah 14 hari.

Setelah 3 minggu paska tindakan tampak penyembuhan luka baik, ukuran keloid mengecil (gambar 8). Pasien direncanakan injeksi triamsinolon asetonid $40 \mathrm{mg}$ intralesi 1 minggu lagi untuk mencegah rekurensi.

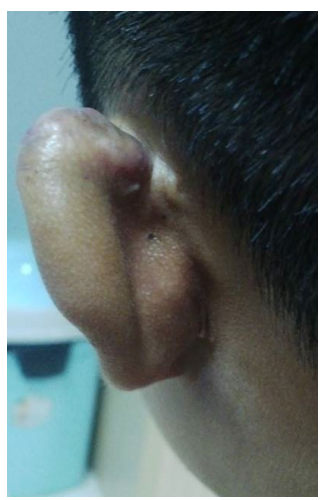

Gambar 8. Tampak penyembuhan luka baik ukuran keloid mengecil.

\section{PEMBAHASAN}

Tingkat keberhasilan revisi keloid meningkat dengan kombinasi dua modalitas terapi. Kombinasi paling sering dilakukan operasi dan injeksi triamsinolon asetonid. ${ }^{5}$ Pada pasien ini kami lakukan pembedahan karena lesi tunggal dengan bentuk lesi pedunculated. Nilasari, dkk. (2010) melaporkan keloid retroaurikuler diterapi dengan kombinasi eksisi diikuti oleh injeksi triamsinolon asetonid $10 \mathrm{mg} / \mathrm{ml}$ intralesi paska operasi. Triamsinolon asetonid $10 \mathrm{mg} / \mathrm{ml}$ disuntikkan mingguan untuk bulan pertama memberikan hasil yang baik. ${ }^{8}$

\section{SIMPULAN}

Teknik debulking keloid memberikan hasil yang baik pada bentuk lesi pedunculated.

\section{DAFTAR PUSTAKA}

1. Burrows NP, Lovell CR. Disorders of connective tissue. Dalam: Burns T, Breatnach S, Cox N, Griffiths C, editors. Rooks Text Book of Dermatology. Edisi kedelapan. Oxford: Blackwell science. 2010; 45:54-5.

2. Mari W, Alsabri SG, Tabal N, Younes S, Sherif A, Simman R. Novel insights on understanding of keloid scar: article review. J Am Coll Clin Wound Spec. 2015; 7(1-3):1-7.

3. Scrimali L, Lomeo G, Nolfo C, Pompili G, Tamburino S, CAtalani A, dkk. Treatment of hypertrophic scars and keloids with a fractional CO2 laser: a personal experience. J Cosmet Laser. 2010; 12:218-21.

4. Chike-Obi CJ, Cole PD, Brissett AE. Keloids: pathogenesis, clinical features, and management. Seminars in Plastic Surgery. 2009; 23(3):178-84

5. Yulistin E, Waskito F, Wirohadidjojo YW. The effect of combination of triamcinolone acetonide and methotrexate on keloid-fibroblast activity in dermis equivalent. IImu Kedokteran Berkala. 2008; 40(2):95-100.

6. Studdiford J, Stonehouse A, Altshuler M, Rinzler E. The Management of Keloids: Hands-On Versus Hands-Off. J Am Board Fam Med. 2008; 21(2):149-52

7. Ako T, Giderog lu K, Akan M. Combination of Different Techniques for the Treatment of Earlobe Keloids. Aesth Plast Surg. 2002; 26:1848.

8. Nilasari I, Rosita C, Oeria S. Terapi keloid retroaurikuler dengan kombinasi surgical dan suntikan triamsinolon asetonid intralesi. MDVI. 2010; 37:19-23 